\title{
ПРАВОВІ НАСЛІДКИ ПРИПИНЕННЯ ШЛЮБУ ЗА ЗАКОНОДАВСТВОМ УКРАЇНИ
}

Грицишина Л. В.

Стаття присвячена питанням правових наслідків припинення шлюбу за законодавством України. Наголошено, що припинення шлюбу не завжди тягне за собою абсолютне припинення правових відносин між подружжям. Підкреслено, що специфіка правових наслідків припинення шлюбно-сімейних правовідносин визначається безпосередньо підставою припинення шлюбу. У характеристиці правовідносин, які виникають при цьому, слід враховувати, чи продовжує колишнє подружжя фактично брати участь у правовідносинах, що виникають після припинення шлюбу, або така участь не $\epsilon$ можливою (смерть одного з подружжя або оголошення його померлим).

У зв'язку з цим запропоновано внести доповнення до сm. 109 СК України, відповідно до якого серед інших питань, що розглядаються судом у разі розірвання шлюбу, вказати порядок здійснення батьківських прав. Названий порядок передбачає не тільки встановлення місця, часу, тривалості зустрічей дитини з батьками, які проживають окремо, але і можливість прийняття в певних випадках рішення одним з батьків.

Підкреслено, що важливою проблемою, яка виникає у разі розірвання шлюбу, є здійснення законного представництва інтересів неповнолітньої дитини. За роздільного проживання батьків роль законного представника неповнолітнього часто належить тому з батьків, хто є його безпосереднім вихователем. Здається, що таке трактування положень СК України веде до порушення особистого немайнового права батька, що проживає окремо від своєї колишньої сім'ї.

Наголошено, що реалізація права на вибір прізвища у разі розірвання шлюбу через збереження прізвища колишнього чоловіка, вибраного загальним під час вступу в шлюб, принципово порушує право на ім'я іншого з подружжя. У зв'язку з цим необхідно передбачити в законі обов'язкове отримання згоди чоловіка (колишнього чоловіка) на використання його прізвища колишньою дружиною.

Ключові слова: шлюб, припинення шлюбу, підстави припинення шлюбу, розлучення, діти, наслідки припинення шлюбу.

Hrytsyshyna L. V. Legal consequences of termination of marriage under the law of Ukraine

The article is devoted to the issues of legal consequences of termination of marriage under the law of Ukraine. It is emphasized that the termination of marriage does not always entail an absolute termination of the legal relationship between husband and wife. It is mentioned that the specifics of the legal consequences of termination of marital and family relations are determined directly by the grounds for termination of marriage. In characterizing the legal relationship that arises, it should be taken into account whether the former spouses continue to actually participate in the legal relationship that arises after termination of marriage, or such participation is impossible (death of one of the spouses or declaring that she/he is dead).

In this regard, it is suggested to amend Art. 109 of the FC of Ukraine, according to which, among other issues considered by the court in the termination of marriage, indicate the procedure for exercising parental rights. This procedure involves not only the establishment of place, time, duration of meetings of a child a parent, who lives separately, but also the possibility of decision-making in certain cases by one of the parents.

It is underlined that an important issue that arises during divorce is the implementation of legal representation of the interests of a minor child. In the case of separate residence of parents, the role of the legal representative of the minor child often belongs to the parent who is his direct minder. It seems that such an interpretation of the provisions of the FC of Ukraine leads to a violation of the personal non-property rights of a parent who lives separately from his/her former family.

It is emphasized that the exercise of the right to choose a surname in case of divorce through keeping the surname of the ex-husband, chosen as common one at the time of marriage, fundamentally violates the right to the name of the other spouse. In this regard, it is necessary to provide in the law the mandatory consent of the husband (ex-husband) to use his name by the other spouse.

Key words: marriage, termination of marriage, grounds for termination of marriage, divorce, children, consequences of divorce.

Постановка проблеми та їі актуальність. Традиційно в науці сімейного права під припиненням шлюбу розуміється зумовлене настанням певних обставин припинення правовідносин, що виникають між подружжям у результаті державної

(с) Грицишина Л. В., 2020 
реєстрації шлюбу. Відповідно, така ознака шлюбного союзу, як добровільність, у науці сімейного права розглядається як ознака не тільки укладення, але і припинення шлюбу.

Водночас припинення шлюбу не завжди тягне за собою абсолютне припинення правових відносин між подружжям. Більш того, якщо у разі розірвання шлюбу у подружжя $є$ спільні діти, то наслідки, що виникають у разі його припинення, торкаються прав і інтересів дітей, що, своєю чергою, тягне за собою виникнення або зміну правовідносин за їх участю.

Також, незважаючи на традиційну точку зору про повне припинення правовідносин між подружжям, правові наслідки у сфері особистих немайнових і майнових відносин між колишнім подружжям наступають за будь-якої з підстав припинення шлюбу [1].

Аналіз останніх досліджень і публікацій. Дисертаційні дослідження українських учених розглядають окремі питання щодо припинення шлюбу, такі як: «Правове регулювання припинення шлюбу за законодавством України» (О.І. Сафончик), «Укладення та розірвання шлюбу за законодавством України» (О.Ю. Бикова), «Правове регулювання розлучення за сімейним законодавством України» (К.М. Глиняна), «Припинення шлюбу за законодавством України» (А.Б. Болховітінова). Питання розірвання шлюбу розглядають у працях В.А. Ватраса [2], А.О. Дутко [3], О.І. Сафончик [4] та інших дослідників сучасного та радянського періодів. Однак практично поза увагою науковців залишилось питання розірвання шлюбу з окремими категоріями осіб, що, зрештою, й зумовлює нагальність цього дослідження.

Метою статті $є$ дослідження питання правових наслідків припинення шлюбу у сімейному праві України задля пошуку можливих шляхів вирішення проблемних питань у цій сфері.

Виклад основного матеріалу дослідження. Невід'ємною частиною правовідносин з припинення шлюбу виступають правові наслідки припинення шлюбу, визначені у межах глави 11 СК України [1]. Йдеться про право на вибір прізвища після розірвання шлюбу (ст. 113 СК України), реєстрацію розірвання шлюбу (ст. 115 СК України), право на повторний шлюб після розірвання шлюбу (ст. 116 СК України), право на поновлення шлюбу після його розірвання (ст. 117 СК України) та можливості поновлення шлюбу у разі з'явлення особи, яка була оголошена померлою або визнана безвісно відсутньою [4].
Згадана нами O.I. Сафончик наголошує, що «правові наслідки припинення шлюбу складаються з припинення надалі особистих і майнових правовідносин, що існували між подружжям під час шлюбу. При цьому одні правовідносини припиняються відразу після припинення шлюбу, інші можуть бути збережені або за бажанням подружжя або через пряме встановлення закону [5]. 3 огляду на вищезазначене, автор наводить таку класифікацію правових наслідків, що виникають у зв'язку з припиненням шлюбу, взявши за основу критерій правової природи їх прав (майнових та особистих немайнових). Так, О.І. Сафончик вказує: «Правові наслідки немайнового характеру, що виникають: між подружжям (повторний шлюб, поновлення шлюбу, зміна прізвища тощо); між подружжям і дітьми (з ким проживатимуть діти після припинення шлюбу, можлива зміна прізвища дитини, участь батьків у вихованні дитини після припинення шлюбу тощо); між подружжям, дітьми та іншими особами (участь діда, баби, прабаби, прадіда у вихованні онуків, правнуків; можливість спілкування братів, сестер, які проживають окремо, тощо). Правові наслідки майнового характеру: між подружжям (розподіл майна, аліментні відносини, спадкування); між подружжям і дітьми (розподіл майна, аліментні відносини, спадкування); між подружжям, дітьми та іншими особами (розподіл майна, спадкування)» [5].

Зрозуміло, що вся гама суспільних відносин, пов'язаних з припиненням шлюбу, не вичерпується окресленими вище положеннями. Тобто законодавець залишає за межами державного втручання і своєї уваги значну частину шлюбно-подружніх відносин.

У цьому контексті В.А. Ватрас наводить власну класифікацію сімейних правовідносин, включаючи до них і «колишнє подружжя»: «Виходячи із зазначеного, можна виділити таку класифікацію сімейних правовідносин залежно від їх суб'єктного складу: правовідносини між подружжям, особами, що перебувають у фактичних шлюбних відносинах, та колишнім подружжям (подружні і прирівняні до них правовідносини); правовідносини батьків та дітей; правовідносини між близькими родичами та особами, що до них прирівнюються (родинні правовідносини)» [6].

Досить часто ситуація може бути ускладнена наявністю неповнолітніх дітей, народжених у шлюбі, оскільки правовий режим здійснення батьківських прав залишається незмінним, незалежно від факту розірвання шлюбу батьків, а також необхідністю вирішення питання про 
надання можливого аліментного утримання. Особисті немайнові та майнові відносини між колишнім подружжям, яке як має, так і не має дітей на момент припинення шлюбу, $є$ дуже різноманітними та можуть бути врегульовані як законом, так і угодами сторін. У зв'язку з цим доцільно визначити пріоритети в механізмі правового впливу на відносини між колишнім подружжям, батьками і дітьми.

Досить цікавою $є$ позиція, за якою розірвання шлюбу за своєю природою необхідно тлумачити як спосіб захисту прав подружжя, що являє складний юридичний склад, який включає у себе сукупність юридичних фактів - дій, спрямованих на забезпечення i захист особистих i майнових прав подружжя, що має намір розірвати шлюб. При цьому засобами захисту прав подружжя, яке перебуває у процесі припинення шлюбу, $\epsilon$ конкретні дії, спеціальні прийоми, які не суперечать законодавству, спрямовані на реалізацію прав подружжя на розірвання шлюбу, здійснювані в юрисдикційній і неюрисдикційній формах самим подружжям або третіми особами з метою захисту прав подружжя в рамках триваючих правовідносин з розірвання шлюбу.

Підкреслимо, що специфіка правових наслідків припинення шлюбно-сімейних правовідносин визначається безпосередньо підставою припинення шлюбу. У характеристиці правовідносин, які виникають при цьому, слід враховувати, чи продовжує колишнє подружжя фактично брати участь у правовідносинах, що виникають після припинення шлюбу, або така участь не $є$ можливою (смерть одного з подружжя або оголошення його померлим).

Названі та інші фактори не можуть позитивним чином позначатися на діяльності законодавця i у разі правозастосування у сфері особистих немайнових і майнових відносин, що складаються під час припинення шлюбу.

Припинення шлюбу як юридичний акт припиняє правові відносини між подружжям на майбутнє, однак:

- розірвання шлюбу не припиняє права особи на утримання, яке виникло у неї за час шлюбу (ст. 76 СК України);

- розірвання шлюбу не припиняє права спільної сумісної власності на майно, набуте за час шлюбу (ст. 68 СК України).

Припинення шлюбу тягне за собою припинення особистих прав та обов'язків (статті 51, 52, 54, 55, 56 CK) [1]. При цьому деякі з них припиняються саме з моменту розірвання шлюбу, а деякі за бажанням одного з подружжя чи відповідно до закону продовжують тривати ще певний час.

Розірвання шлюбу також означає припинення режиму спільної сумісної власності подружжя. Речі, набуті кожною особою після розірвання шлюбу, належать їй на праві приватної власності. Разом із тим особливістю відносин колишнього подружжя $\epsilon$ те, що стосовно майна, яке було набуте під час шлюбу, режим спільної сумісної власності зберігається до моменту поділу такого майна. Втрачається право на спадщину за законом після смерті колишнього чоловіка/дружини, право на пенсійне забезпечення у зв'язку із втратою другого з подружжя за встановленими у законі підставами тощо [7].

Можуть зберігатися деякі взаємні права та обов'язки (право на отримання аліментів від колишнього чоловіка/дружини, право на спільне майно тощо).

Із припиненням шлюбу закон пов'язує також виникнення у подружжя права на утримання [7].

Лише після державної реєстрації розірвання шлюбу, що здійснюється органами реєстрації актів цивільного стану та набранням рішенням суду законної сили, всі особисті немайнові відносини між подружжям будуть припинені. При цьому правові наслідки припинення шлюбу у сфері особистих немайнових відносин між колишнім подружжям, шлюб якого був розірваний у суді, мають одну істотну особливість. Разом із тим можна вести мову про особливий період існування шлюбних правовідносин, коли подружжя (або один з нього, за позовом якого суд розглядає справу у суді) виявило намір припинити шлюб, але юридично сімейно-шлюбні правовідносини між ними зберігаються.

Таким чином, припинення шлюбу є особливим періодом (триваюче правовідношення), в процесі якого відбувається зміна правових відносин між подружжям, що вимагає врахування різноманітних правових інтересів такого подружжя та членів їх сімей.

Специфіка правових наслідків усфері особистих немайнових відносин між колишнім подружжям втілюється в особливому юридичному значенні факту реєстрації розірвання шлюбу. При цьому необхідно враховувати положення ст. 15 Закону України «Про державну реєстрацію актів цивільного стану» від 1 липня 2010 року № 2398-VI, відповідно до якої «державна реєстрація розірвання шлюбу подружжя, яке не має дітей, проводиться відповідним органом державної реєстрації актів цивільного стану за місцем проживання подружжя 
або одного з нього за їх заявою» (ч. 2 ст. 15 Закону України «Про державну реєстрацію актів цивільного стану»), а «про державну реєстрацію розірвання шлюбу та про розірвання шлюбу, здійснене в судовому порядку, робиться відмітка в актовому записі про шлюб» (ч. 7 ст. 15 Закону України «Про державну реєстрацію актів цивільного стану»). При цьому у разі розірвання шлюбу в судовому порядку рішення суду, яке набрало законної сили, надсилається судом до органу державної реєстрації актів цивільного стану за місцем ухвалення рішення [8].

Отже, у разі розірвання шлюбу органами реєстрації актів цивільного стану, з моменту подання заяви про припинення шлюбу до отримання свідоцтва про розірвання шлюбу, жоден із подружжя не зможе вступити в новий шлюб, відповідно у кожного з них зберігається обов'язок немайнового характеру.

На окрему увагу також заслуговують і положення ч. 6 ст. 15 Закону України «Про державну реєстрацію актів цивільного стану», відповідно до якого «той з подружжя, який бажає відновити Своє дошлюбне прізвище, повинен заявити про це в органі державної реєстрації актів цивільного стану під час державної реєстрації розірвання шлюбу» [8].

Таким чином, і під час розгляду справи в суді або винесення у справі рішення, яке не набуло законної сили, у подружжя, яке перебуває в процесі припинення шлюбу, продовжують існувати певні права до моменту набрання цим рішенням законної сили. Водночас окремі з них можуть мати i так звану «переживаючу» дію (продовжувати існування і після припинення шлюбу).

Наприклад, це може навіть втілитися у тому, що один з подружжя за цей період може отримати прізвище іншого. Необхідно зауважити, що реалізація права на вибір прізвища у разі розірвання шлюбу через збереження прізвища колишнього чоловіка, вибраного як загальне під час вступу в шлюб, принципово порушує право на ім'я іншого з подружжя. У зв'язку з цим необхідно передбачити в законі обов'язкове отримання згоди чоловіка (колишнього чоловіка) на використання його прізвища колишньою дружиною.

Зазначене дозволить уникнути ситуації, яка мала місце у справі, коли після розірвання шлюбу Х. продовжувала користуватися шлюбним прізвищем - Іваненко. Через два роки після розірвання шлюбу вона народила дитину. У свідоцтві про народження дитини у графі «батько» вона вказала «Іваненко», а ім'я та по батькові батька зі слів матері було записано - Денис Сергійович. Саме таким було ім'я та по батькові ії колишнього чоловіка. Колишній чоловік звернувся до суду, вважаючи запис себе батьком дитини незаконним. Суд у задоволенні позову відмовив, оскільки відповідно до нині чинних положень СК України дії колишньої дружин були правомірними [9, с. 237].

Вважаємо також за можливе часткове запозичення зарубіжного досвіду і в частині включення в шлюбний договір умов, що регулюють особисті немайнові відносини між подружжям (колишнім подружжям), що дозволить заздалегідь передбачити можливі варіанти здійснення окремих особистих немайнових прав та обов'язків подружжя (колишнього подружжя). До таких питань можна віднести участь колишнього подружжя у вихованні спільної дитини (дітей) після припинення шлюбу між ними.

Так, питання про визначення місця проживання дитини у разі розірвання шлюбу може бути вирішене судом. Визначення ж порядку спілкування з дитиною і здійснення своїх батьківських прав загалом колишнім подружжям і насамперед тим з нього, хто проживає окремо від дитини, не входить в обов'язок суду під час розгляду справи про розірвання шлюбу. Це означає, що правові наслідки розірвання шлюбу в сфері особистих немайнових відносин між батьками і дітьми частково повинні бути визначені рішенням суду, проте це не виключає їх повної регламентації за допомогою укладення між батьками відповідної угоди.

Подібні угоди між батьками, з яких один уже проживає окремо від дитини або буде проживати окремо після розірвання шлюбу, $\epsilon$ угодою особливого виду. Ї̈̈ зміст можуть становити умови про місце проживання неповнолітнього, про порядок спілкування дитини і батьків, про порядок здійснення інших батьківських прав і обов'язків, у тому числі зі сплати аліментів на утримання неповнолітньої дитини. Також досить важливою проблемою, яка виникає у разі розірвання шлюбу, $\epsilon$ здійснення законного представництва інтересів неповнолітньої дитини. У разі роздільного проживання батьків роль законного представника неповнолітнього часто належить тому з батьків, хто $€$ його безпосереднім вихователем. Здається, що таке трактування положень СК України веде до порушення особистого немайнового права батька, що проживає окремо від своєї колишньої сім'ї.

Розглядаючи справу про розірвання шлюбу, суд може не тільки вирішити, з ким із батьків будуть проживати неповнолітні діти після розлучення, але i визначити порядок здійснення 
батьківських прав кожним з батьків, а не тільки того, хто проживає окремо від дитини. На нашу думку, передбачене законом поняття «здійснення батьківських прав батьків, які проживають окремо від дитини» суперечить самій суті батьківських прав, їх єдності і належності кожному з батьків. Здійснення прав одним з батьків передбачає також врахування прав та інтересів другого з батьків, з ким проживає дитина.

Висновки. Підсумовуючи, наголосимо на таких важливих положеннях. Так, припинення шлюбу необхідно вважати особливим періодом (триваючим правовідношенням), у процесі якого відбувається зміна правових відносин між подружжям. Ці правовідношення вимагають врахування різноманітних правових інтересів такого подружжя та членів їхніх сімей.

Специфіка правових наслідків припинення шлюбно-сімейних правовідносин визначається безпосередньо підставою припинення шлюбу. У характеристиці правовідносин, які виникають при цьому, слід враховувати, чи продовжує колишнє подружжя фактично брати участь у правовідносинах, що виникають після припинення шлюбу, або така участь не $\epsilon$ можливою (смерть одного з подружжя або оголошення його померлим).

У зв'язку з цим виглядає доцільним внести доповнення до ст. 109 СК України, відповідно до якого серед інших питань, що розглядаються судом у разі розірвання шлюбу, вказати порядок здійснення батьківських прав. Названий порядок передбачає не тільки встановлення місця, часу, тривалості зустрічей дитини з батьками, які проживають окремо, але i можливість прийняття в певних випадках рішення одним з батьків.

Також досить важливою проблемою, яка виникає у разі розірвання шлюбу, є визначення законного представництва інтересів неповнолітньої дитини. У разі роздільного проживання батьків роль законного представника неповнолітнього часто належить тому з батьків, хто $є$ його безпосереднім вихователем. Здається, що таке трактування положень СК України веде до порушення особистого немайнового права батька, що проживає окремо від своєї колишньої сім'ї.

Наголошено, що реалізація права на вибір прізвища у разі розірвання шлюбу через збереження прізвища колишнього чоловіка, вибраного загальним під час вступу в шлюб, принци- пово порушує право на ім'я іншого з подружжя. У зв'язку з цим необхідно передбачити у законі обов'язкове отримання згоди чоловіка (колишнього чоловіка) на використання його прізвища колишньою дружиною.

\section{Література}

1. Сімейний кодекс України від 10.01.2002 р. № 2947-III. / Верховна Рада України. Законодавство України. URL: https://zakon.rada.gov.ua/laws/ show/2947-14.

2. Ватрас В.А. Особливості суб'єктного складу подружніх і прирівняних до них правовідносин. Університетські записки, 2009. № 1(29). С. 65-70.

3. Дутко А.О. Розірвання шлюбу за законодавством України. Вісник Національного університету «Львівська політехніка», 2014. № 5. С. 51-55.

4. Сафончик О.І. Поняття припинення шлюбу та його відмінність від визнання шлюбу недійсним за законодавством України. Вісник Чернівецького факультету Національного університету «Одеська юридична академія». 2017. № 3. С. 51-60.

5. Сафончик О.І. Правові наслідки припинення шлюбно-сімейних правовідносин за законодавством України та країн Євросоюзу. Часопис цивілістики. 2017. Вип. 24. С. 79-82.

6. Ватрас В.А. Суб'єкти сімейних правовідносин : дис. ... канд. юрид. наук : 12.00.03. Київ, 2008. 227 с.

7. Розгон О. Припинення шлюбу в разі його розірвання та визнання фіктивним: відмінності між правовими наслідками на прикладах судової практики. Вісник Національної асоціації адвокатів України. 2018. № 9 (46). С. 25-35.

8. Про державну реєстрацію актів цивільного стану : Закон України від 1 липня 2010 року № 2398-VI. / Верховна Рада України. База даних «Законодавство України». URL: https:// zakon.rada.gov.ua/laws/show/2398-17\#Text.

9. Ромовська 3.В. Сімейний кодекс України : науково-практичний коментар. Київ : Видавничий Дім «Ін Юре», 2003. 532 с.

Грицишина Л. В., ORCID 0000-0002-8590-728X

аспірант кафедри цивільного права та процесу Хмельницького університету управління та права імені Леоніда Юзькова 